\title{
THE EFFECT OF NON-PERFORMING LOAN, CAPITAL ADEQUACY RATIO, LOAN TO DEPOSIT RATIO AND OPERATING EXPENSES TO OPERATING INCOME ON DEPOSIT PORTFOLIO OF NATIONAL SOCIAL SECURITY ON EMPLOYMENT (BPJS KETENAGAKERJAAN) FOR PERIOD OF 2015-2017
}

\author{
Lubis Marisa $^{1 *}$, Mustafa Matrodji ${ }^{2}$ \\ ${ }^{1}$ Magister of Management, Postgraduate Program of University Mercu Buana, Indonesia \\ ${ }^{2}$ Lecturer of Magister of Management, Postgraduate Program of University Mercu Buana, \\ Indonesia \\ *E-mail: marisalubis23@gmail.com \\ ORCID: 0000-0002-6671-9507
}

\begin{abstract}
The objective of this research is to examine and analyze the impact of non-performing loan, capital adequacy ratio, loan to deposit ratio and operating expenses to operating income to the portfolio of deposit of BPJS Ketenagakerjaan. Sampling was conducted with a census sampling method during 2015-2017. The results show that capital adequacy ratio have positive significant influence on deposit of BPJS Ketenagakerjaan.
\end{abstract}

\section{KEY WORDS}

Deposit, social security, employment, non-performing loan, capital adequacy ratio, loan to deposit ratio, operational expenses.

The financial sector plays a very important role in fastering economic growth of a country. The financial sector becomes the locomotive of real sector growth through capital accumulation and technological innovation. More precisely, the financial sector is able to mobilize savings and channel it to those in need through credit provision. They provide a variety of financial instruments to the owners of funds with high quality and low risk. It will increase investment and ultimately accelerate economic growth. One of the institutions in the financial sector is a banking institution. According to the banking law No. 10 of 1998 Article 1 (2), it is explained that the meaning of a bank is a business entity that collects funds from the community in the form of savings and distributes to the community in the form of credit and or other forms in order to improve the standard of living of many people.

The function of banks in channeling funds from depositors to borrowers is not without risk. Debtor risk cannot pay off the loan and the interest is called credit risk. The failure of banks in lending will cause losses that may affect the ability of banks to provide funds to meet the withdrawal of customer deposits. Risk management in banking financial institutions becomes one of the important elements, both concerning the success and the failure of the bank's business. Based on Bank of Indonesia regulation Number 11/25/PBI/2009 of 2009, it is that with the increasing complexity of bank products and activities, the risks faced by banks will increase, with risks faced by banks need to be balanced with the quality of risk management implementation.

For savers or depositors in the bank, it is needed caution because saving money in the bank is not without risks, especially the security risks of the deposit money. In the relationship between banks and depositors, the depositors are not fully aware of the true state of the bank. It makes the depositors unable to make the right decisions. It is called asymmetric information. On the other hand, the occurrence of asymmetric information manifested in the form of high transaction costs and information costs in financial markets can be minimized if the financial sector functions efficiently (Levine, 1997).

Outline of National Social Security on Employment (BPJS Ketenagakerjaan) Investment Policy. BPJS Ketenagakerjaan is a financial institution in an insurance family that receives premiums from participants. This premium is the main source of $B P J S$ revenue and 
is used to pay the claims of the participants. BPJS should invest this premium income in various financial assets. Money lenders in the bank including National Social Security on Employment (BPJS Ketenagakerjaan) wants their money in the bank to be secure and can be taken back when needed or at maturity. These depositors want the bank to keep the money healthy. To protect the interests of these depositors, the banks must be arranged to stay healthy.

Deposit of National Social Security on Employment (BPJS Ketenagakerjaan) in various banks is an investment, and then National Social Security on Employment needs to analyze the extent to which money invested in the deposit is safe. Not only whether the bank is healthy or not but also seen the risks facing the bank. In accordance with the theory of investment of National Social Security on Employment (BPJS Ketenagakerjaan) should consider two factors: risk and return.

Many types of risks can cause a bank unable to meet withdrawal of funds by customers. These risks can cause losses to the bank so that the bank is unable to meet the withdrawal of funds by the customer. In general, the risks faced by banks include Credit Risk, Market Risk, Liquidity Risk, and Operational Risk. According to Bank of Indonesia Regulation Number 11/25/PBI/2009 of 2009, there are several risks in the banking sector, namely credit risk, market risk, operational risk, liquidity risk, strategic risk, reputation risk, legal risk, and compliance risk.

The depository customer must realize that saving money in the bank is not always safe if the bank is not healthy because it is not good at managing the risks. All depositors including National Social Security on Employment (BPJS Ketenagakerjaan) should be aware of the risks facing the bank and analyze the results of bank risk management before deciding to cooperate in the placement of deposits. Risk management in banking financial institutions becomes one of the important elements, both concerning the success and the failure of the bank's business. Based on Bank of Indonesia regulation Number 11/25/PBI/2009 of 2009, it is that with the increasing complexity of bank products and activities, the risks faced by banks will increase, with risks faced by banks need to be balanced with the quality of risk management implementation.

Based on the support of the theory according to Kamau and Njeru (2015), there are several risks faced by banks such as: credit risk, liquidity risk, and operational risk. Syafi'i and Rusliati (2016) expose risks directly related to the banking business such as market risk that may affect third party fund collection, credit risks arising from the failure of customers to meet their obligations, and operational risks resulting from inadequate internal processes, human error, system failure, and or any external event affecting bank operations (Basel II).

According to Saeed (2014), it is argued that banks need to manage risk in an integrated manner and to create the system, management structure required to achieve these objectives, Bank of Indonesia requires four risks: market risk, credit risk, operational risk, and liquidity risk. The biggest investment result of National Social Security on Employment (BPJS Ketenagakerjaan) employment currently is obtained from Deposits, the researcher is interested in this because in general the investment that produces the maximum return is usually from property, bonds and if the condition of normal or good markets then the stock has a high potential return. By this, the researcher conducts study whether these four risks have the same effect as previous researchers on the placement of National Social Security on Employment (BPJS Ketenagakerjaan) deposit portfolio or not at all.

Research Problem. Based on the background that has been previously explained, then the problems in this study are as follows:

- Does NPL faced by banks affect the amount of deposits placed by National Social Security on Employment (BPJS Ketenagakerjaan)?

- Does CAR faced by the bank affect the amount of deposits placed by National Social Security on Employment (BPJS Ketenagakerjaan)?

- Does LDR faced by banks affect the amount of deposits placed by National Social Security on Employment (BPJS Ketenagakerjaan)? 
- Does Operating Expenses to Operating Income affect the amount of deposits placed by National Social Security on Employment (BPJS Ketenagakerjaan)?

- Do NPL, CAR, LDR, Operating Expenses to Operating Income simultaneously affect the amount of deposits placed by National Social Security on Employment (BPJS Ketenagakerjaan)?

Research Objectives. The objectives of this research are:

- To know how the impact of NPL on the deposit placement amount of National Social Security on Employment (BPJS Ketenagakerjaan) deposit portfolio;

- To know how the impact of CAR on the deposit placement amount of National Social Security on Employment (BPJS Ketenagakerjaan) deposit portfolio;

- To know how the impact of LDR on the deposit placement amount of National Social Security on Employment (BPJS Ketenagakerjaan) deposit portfolio;

- To know how the impact of Operating Expenses to Operating Income on the deposit placement amount of National Social Security on Employment (BPJS Ketenagakerjaan) deposit portfolio;

- To know how NPL, CAR, LDR, Operating Expenses to Operating Income affect simultaneously the amount of deposit placement portfolio by the impact of credit risk on the deposit placement amount of National Social Security on Employment (BPJS Ketenagakerjaan) deposit portfolio.

\section{METHODS OF RESEARCH}

Research Type. Based on the research objective which is to know how the effect of NPL, CAR, LDR and Operating Expenses to Operating Income on National Social Security on Employment (BPJS Ketenagakerjaan) deposit portfolio. Thefore, the type of research used is causal research. Sekaran and Roger (2013) states that a study included in causal research is to prove the causal relationship of several variables. Causal research usually uses experimental method that is by controlling the independent variables that will affect the dependent variable on the planned situation.

Research Model. This study examines the effect of credit risk, market risk, liquidity risk, and operational risk on the amount of deposits placed by National Social Security on Employment (BPJS Ketenagakerjaan) at banks. The form of equation used can be seen in Eq. (1).

$$
\mathrm{Y}_{\mathrm{it}}=\mathrm{a}_{\mathrm{i}}+\beta_{1} \mathrm{X} 1_{\mathrm{it}}+\beta_{2} \mathrm{X} 2_{\mathrm{it}}+\beta_{3} \mathrm{X} 3_{\mathrm{it}}+\beta_{4} \mathrm{X} 4_{\mathrm{it}}+\varepsilon_{\mathrm{it}}
$$

Where:

- $\mathrm{Y}_{\mathrm{it}}=$ Total deposits owned by BPJS in bank i year $\mathrm{t}$;

- $\quad \mathrm{X}_{\mathrm{it}}=\mathrm{NPL}$ faced by bank $\mathrm{i}$ year $\mathrm{t}$;

- $\mathrm{X} 2_{\mathrm{it}}=\mathrm{CAR}$ faced by bank i year $\mathrm{t}$;

- $\quad \mathrm{X}_{\mathrm{it}}=\mathrm{LDR}$ faced by bank i year $\mathrm{t}$;

- $X 4_{i t}=$ Operating Expenses to Operating Income faced by bank i year t;

- $\mathrm{a}_{\mathrm{i}}=$ Constants;

- $\beta_{1}, \beta_{2}, \beta_{3}$ and $\beta_{4}=$ Regression Coefficient;

- $\varepsilon_{i t}=$ Error.

Population and Sampling. The population in this study is a banking company listed as a cooperation Bank of National Social Security on Employment (BPJS Ketenagakerjaan) in managing investments, especially in the money market from 2015 until 2017. The population in this study is a banking company registered as a bank deposit of National Social Security on Employment (BPJS Ketenagakerjaan) of 29 banks. Sample selection procedure in this study is to use census sampling that is all the population used as a sample by the 
researcher. A list of banks listed as Deposit Bank of National Social Security on Employment (BPJS Ketenagakerjaan) can be seen in Table 1.

Table 1 - Banking Companies that are Research Sample

\begin{tabular}{|l|l|}
\hline \multicolumn{1}{|c|}{ No } & \\
\hline 1 & PT Bank Mandiri Tbk \\
\hline 2 & PT Bank Negara Indonesia Tbk \\
\hline 3 & PT Bank Tabungan Negara Tbk \\
\hline 4 & PT Bank Rakyat Indonesia Tbk \\
\hline 5 & PT Bank Aceh Syariah Tbk \\
\hline 6 & PT Bank Sumut \\
\hline 7 & PT Bank Nagari \\
\hline 8 & PT Bank Sumselbabel \\
\hline 9 & PT Bank Lampung \\
\hline 10 & PT Bank Jambi \\
\hline 11 & PT Bank BJB \\
\hline 12 & PT Bank Jateng \\
\hline 13 & PT Bank Sulteng \\
\hline 14 & PT Bank Sulutgo \\
\hline 15 & PT Bank Sulsebar \\
\hline 16 & PT Bank Kalbar \\
\hline 17 & PT Bank Kalsel \\
\hline 18 & PT Bank Papua \\
\hline 19 & PT Bank Bali \\
\hline 20 & PT Bank Kepri \\
\hline 21 & PT Bank NTT \\
\hline 22 & PT Bank Bengkulu \\
\hline 23 & PT Bank NTB \\
\hline 24 & PT Bank DKI \\
\hline 26 & PT Bank Muamalat \\
\hline 28 & PT Bank BTPN \\
\hline & PT Bank CIMB Niaga \\
\hline 29 & PT Bank Maluku \\
\hline
\end{tabular}

Data Collection. Data collection in this research is by method of documentation and literature study. Data collection in this research is done by documenting the recorded annual data listed for NPL, CAR, LDR, BOPO data obtained from www.infovesta.com and for data of National Social Security on Employment (BPJS Ketenagakerjaan) Deposit Portfolio obtained from official website www.bpjsketenagakerjaan.go.id.

Panel Data Estimation Model. Panel Data Estimation Model according to Wanner and Pevalin as cited by Sembodo (2013) mentions that there are two approaches used in estimating the model of panel data ie model without the influence of the individual (common effect) and the model with the influence of the individual (fixed effect and random effect).

Selection of Panel Data Regression Estimation Model. Chow test is used to select one model on panel data regression, ie between fixed effect models with common effect model. The test procedure is as follows (Baltagi, 2005).

- Hausman test is used to select random effect model with fixed effect model. The initial hypothesis is that there is no correlation between model error with one or more explanatory variables. The test procedure is as follows (Baltagi, 2008: 310).

- Breusch-Pagan Test, according to Rosadi (2011) Breusch-Pagan test is used to test the effects of time, individual, or both.

Panel Data Regression Analysis. Panel data regression analysis is based on selected regression model (from common, fixed, and random efefect). This research data analysis method uses panel data analysis as a data processing tool using Eviews software. The analysis using the data panel is a combination of time series and cross section data. By accommodating the information model both related to cross section and time series 
variables, panel data can substantially decrease the omitted variable problem, a model that ignores the relevant variables (Wibisono, 2005).

Hyphotesis Test. This test is done to know whether there is influence of Non Performing Loan, Capital Adequacy Ratio, Loan to Deposits Ratio and Operating Expenses to Operating Income to the Bank's financial performance in commercial banks in 2015 to 2017 period. To test the effect of the independent variable $(X)$ to the dependent $(Y)$ both partially or jointly is done with the determinant coefficient (R2), statistical tests (t-test), and test $F(F-$ test $)$.

\section{RESULTS OF STUDY}

Descriptive Statistics Analysis. This research is banking which is included in Bank cooperation with National Social Security on Employment (BPJS Ketenagakerjaan) in period of 2015 until 2017. Banks included in the Bank during the research period are 29 Banks, therefore, the data used in this study are 29 data. Data processing utilizes Eviews 10. The data in this study included secondary data obtained from official sites of infovesta, Bank of Indonesia and National Social Security on Employment (BPJS Ketenagakerjaan). Data obtained is quantitative data for both independent variable data and dependent data. The following descriptive statistics of NPL, CAR, LDR, BOPO and Deposit Placement of National Social Security on Employment (BPJS Ketenagakerjaan).

Table 2 - Descriptive Statistics

\begin{tabular}{|lcccccc|}
\hline & PENEMPATAN & C & NPL & CAR & LDR & BOPO \\
Mean & 1156.057 & 1.000000 & 1.372644 & 19.58195 & 78.10632 & 78.88782 \\
Median & 534.5000 & 1.000000 & 0.830000 & 19.39000 & 75.48000 & 78.94000 \\
Maximum & 6999.000 & 1.000000 & 6.810000 & 29.09000 & 111.4900 & 134.1200 \\
Minimum & 23.00000 & 1.000000 & 0.010000 & 12.78000 & 51.94000 & 39.45000 \\
Std. Dev. & 1512.443 & 0.000000 & 1.316511 & 3.795416 & 13.49156 & 10.77628 \\
Skewness & 2.061400 & NA & 1.459441 & 0.392908 & 0.368484 & 1.096945 \\
Kurtosis & 6.519770 & NA & 5.283073 & 2.857799 & 2.524223 & 11.32827 \\
Jarque-Bera & 106.5252 & NA & 49.77957 & 2.311765 & 2.789379 & 268.8781 \\
Probability & 0.000000 & NA & 0.000000 & 0.314780 & 0.247910 & 0.000000 \\
& 100577.0 & 87.00000 & 119.4200 & 1703.630 & 6795.250 & 6863.240 \\
Sum & $1.97 \mathrm{E}+08$ & 0.000000 & 149.0553 & 1238.846 & 15653.90 & 9987.032 \\
Sum Sq. Dev. & & & & & 87 & 87 \\
Observations & 87 & 87 & 87 & 87 & 87 \\
\hline
\end{tabular}

From Table 2, the researcher will examine the calculation result of minimum, maximum, average, and standard deviation from NPL, CAR, LDR and BOPO data found in all banks that have cooperation with National Social Security on Employment (BPJS Ketenagakerjaan). The description is below:

- From Population Data used as sample, it shows NPL has an average value of 1.372644 with a standard deviation of 1.316511 . The highest NPL of $6.81 \%$ is NPL at Bank Muamalat in 2016 and the lowest NPL of $0.01 \%$ is NPL at Bank Kalbar in 2015.

- From Population Data used as sample, CAR has an average value of 19.58195 with a standard deviation of 3.795416 . The highest CAR of 29.09000 by 2015 and the lowest of 12.78000 by 2017 .

- From Population data used as sample reveals LDR has average value of 78.10632 with standard deviation of 13.49156 LDR is 111,49 highest is the LDR at Bank BTN in 2017 and the lowest of 51.94 is the LDR at Bank Bengkulu in 2015.

- From Population data used as sample shows BOPO has average value of 78.88782 with a standard deviation of 10.77628. The highest BOPO of 134.12 is BOPO at Bank Muamalat in 2015 and the lowest is 39.45 is BOPO at Bank BRI in 2017.

- From Population data used as sampple shows Deposit Portfolio (Placement) has

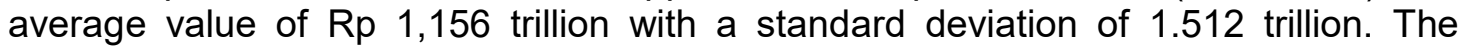


highest deposit of Rp 6,999 trillion is in BNI Bank in 2017 and the lowest of Rp23 billion is the placement of deposits at Bank Sumselbabel in 2017.

Selection Result of Appropriate Model Regression. From the three models examined which are Common Effect model, Model Fixed Effect, and Random Effect Model, the test results are presented below:

Chow Test Results (Chow Test). This research uses panel data type, thus to choose the type of model that will be used need to be tested first. Initial test done in this research is by doing Chow test which is to determine whether this method use common effect or fixed effect. Chow test formulation is:

- Ho: Appropriate model of common effect;

- Ha: Appropriate model of fixed effect.

If the resulted $F$ statistic number or the Cross Section Chi-square number has a Prob of less than $5 \%$, then $\mathrm{Ho}$ is rejected which means the model of the fixed effect is appropriate. If the resulted $F$ statistic number or the Cross Section Chi-square number has Prob greater than $5 \%$, then Ho is accepted which means the common effect model is appropriate.

Table 3 - Chow Test Result

\begin{tabular}{|lrrr|}
\hline $\begin{array}{l}\text { Redundant Fixed Effects Tests } \\
\text { Equation: Untitled } \\
\text { Test cross-section fixed effects }\end{array}$ & & & \\
\hline \hline Effects Test & Statistic & d.f. & Prob. \\
\hline \hline Cross-section F & 12.251955 & $(28,54)$ & 0.0000 \\
Cross-section Chi-square & 173.572838 & 28 & 0.0000 \\
\hline
\end{tabular}

Source: Eviews.10

Level of significance: $\alpha=5 \%$

$\mathrm{HO}$ is rejected because of Prob value Cross-section Chi-square $(0,0000)<\alpha(0.05)$ so that the method used is fixed effect. Furthermore, because $\mathrm{HO}$ is rejected, then the next step is to create a regression random effect and conduct hausman test to select fixed effect or random effect.

Hausman Test Result (Hausman Test). Hausman Test is a test used to determine the best method between fixed effect or random effect. In this test, the null hypothesis $(\mathrm{H} 0)$ is a random effect, while the alternative hypothesis $(\mathrm{H} 1)$ is a fixed effect. Here is the hypothesis statement of hausman test:

- $\mathrm{H}_{0}=$ random effect model is appropriate;

- $\mathrm{H} 1=$ fixed effect model is appropriate.

If the Chi-square statistic number resulted has a Prob less than $5 \%$, then Ho is rejected which means the fixed effect model is appropriate. If the resulted Chi-square statistic number has Prob greater than $5 \%$ then Ho is accepted which means the random effect model is appropriate.

Table 4 - Hausman Test Result

\begin{tabular}{|lrrrr|}
\hline $\begin{array}{l}\text { Correlated Random Effects - Hausman Test } \\
\text { Equation: Untitled } \\
\text { Test cross-section random effects }\end{array}$ & & & \\
\hline \hline Test Summary & Chi-Sq. Statistic & Chi-Sq. d.f. & Prob. \\
\hline \hline Cross-section random & 6.978233 & 4 & 0.1370 \\
\hline
\end{tabular}

Source: Eviews 10. 
The value of Prob.Cross Section Random $(1,000)>(0,05)$ so that model used is random effect then $\mathrm{HO}$ accepted. Then, it is proceed with Lagrange Multiplier test to determine whether we still choose random effect or common effect.

Test of Lagrange Multiplier (Lagrange Multiplier Test). Lagrange Multiplier Test is a test used to determine the best method between common effect or random effect. In this test, the null hypothesis $(\mathrm{HO})$ is the common effect, while the alternative hypothesis $(\mathrm{H} 1)$ is the random effect. Here is the hypothesis statement of Lagrange Multiplier test:

- If, the value Breusch-Pagan Value Cross Section $>\alpha$, then it is common effect;

- If, the value of Breush-Pagan Cross Section $<\alpha$, then select random effect.

Table 5 - Lagrange Multiplier Test Result

\begin{tabular}{|c|c|c|c|}
\hline \multicolumn{4}{|c|}{$\begin{array}{l}\text { Lagrange Multiplier Tests for Random Effects } \\
\text { Null hypotheses: No effects } \\
\text { Alternative hypotheses: Two-sided (Breusch-Pagan) and one-sided } \\
\quad \text { (all others) alternatives }\end{array}$} \\
\hline & \multicolumn{3}{|c|}{ Test Hypothes is } \\
\hline & Cross-section & Time & Both \\
\hline Breusch-Pagan & $\begin{array}{l}56.48780 \\
(0.0000)\end{array}$ & $\begin{array}{l}1.553571 \\
(0.2126)\end{array}$ & $\begin{array}{l}58.04137 \\
(0.0000)\end{array}$ \\
\hline
\end{tabular}

The Breusch-Pagan Cross Section value is $0.000<0.05$, therefore $\mathrm{H} 1$ is accepted which means the best estimation method is still Random Effect.

Hypothesis Testing. Hypothesis test is done based on selected model that is random effect model.

Table 6 - Results from Panel Data of Random Effect

\begin{tabular}{|c|c|c|c|c|}
\hline \multicolumn{5}{|c|}{$\begin{array}{l}\text { Cross-section random effects test equation: } \\
\text { Dependent Variable: PEN EMPATAN } \\
\text { Method: Panel Least Squares } \\
\text { Date: } 04 / 12 / 18 \text { Time: } 19: 06 \\
\text { Sample: } 20152017 \\
\text { Periods included: } 3 \\
\text { Cross-sections included: } 29 \\
\text { Total panel (balanced) observations: } 87\end{array}$} \\
\hline Variable & Coefficient & Std. Error & t-Statistic & Prob. \\
\hline C & 3207.993 & 1473.728 & 2.176788 & 0.0339 \\
\hline NPL & 110.3300 & 166.2427 & 0.663669 & 0.5097 \\
\hline CAR & 25.95062 & 33.48759 & 2.249301 & 0.0002 \\
\hline BOPO & -28.25583 & 12.86552 & -2.196245 & 0.0324 \\
\hline LDR & 5.771721 & 10.91313 & 0.528879 & 0.0032 \\
\hline \multicolumn{5}{|c|}{ Effects Specification } \\
\hline \multicolumn{5}{|c|}{ Cross-section fixed (dum m y variables) } \\
\hline R-squared & 0.896893 & \multicolumn{2}{|c|}{ Mean dependent var } & 1156.057 \\
\hline Adjusted R-squared & 0.835793 & \multicolumn{2}{|c|}{ S.D. dependent var } & 1512.443 \\
\hline S.E. of regression & 612.8800 & \multicolumn{2}{|c|}{ Akaike info criterion } & 15.95591 \\
\hline Sum squared resid & 20283585 & \multicolumn{2}{|c|}{ Schwarz criterion } & 16.89126 \\
\hline Log likelihood & -661.0822 & & 16.33255 \\
\hline F-statistic & 14.67899 & & & 2.450957 \\
\hline Prob(F-statistic) & 0.000000 & \multicolumn{2}{|c|}{ Durbin-Wats on stat } & \\
\hline
\end{tabular}

Based on Table 6, it can be seen from prob F-statistic that this model is a good enough model to use because prob F-statistic $<\alpha(\alpha=5 \%)$ that is equal to 0,0000 . Hence, $\mathrm{HO}$ is rejected and $\mathrm{H} 1$ is accepted because the F-statistic prob is 0.0000 . The Adjusted $R^{2}$ value indicates the extent to which variations of the dependent variable are able to be explained by the independent variable, or in other words, how the model can explain the movement of the dependent variable. The value of Adjusted $R^{2}$ value between $0-1$, the closer to 1 , then the 
model's ability to explain the movement of the dependent variable is better. The result of model estimation used resulted Adjusted $R^{2}$ value of 0.868083 . It means that the model used can explain the dependent variable or deposit portfolio of $86.80 \%$.

$$
Y=3207.993+110.3300 \times 1+25.9506 \times 2+5.7717 \times 3-28.2558 \times 4
$$

The result of hypothesis testing for credit risk variable (NPL) has coefficient of 110,330 which shows the positive direction of NPL variable to deposit portfolio of National Social Security on Employment (BPJS Ketenagakerjaan). A sig value of 0,5097 greater than alpha $(\alpha=0.05)$ indicates that NPL has an insignificant effect on the number of National Social Security on Employment (BPJS Ketenagakerjaan) portfolio deposits. Thus, Ha1 which states that there is a significant impact between Non Performing Loan (NPL) on the Deposit Portfolio of National Social Security on Employment (BPJS Ketenagakerjaan) at the banks which are in cooperation with National Social Security on Employment (BPJS Ketenagakerjaan) is rejected, $\mathrm{H} 01$ accepted that there is no significant impact between Non Performing Loan (NPL) to Deposit Portfolio of National Social Security on Employment (BPJS Ketenagakerjaan) at the banks which are in the cooperation with National Social Security on Employment (BPJS Ketenagakerjaan).

The result of hypothesis testing for Capital Adequacy Ratio (CAR) has coefficient of 25,95062 which shows the positive direction of CAR variable to deposit portfolio of National Social Security on Employment (BPJS Ketenagakerjaan). A sig value of 0.0002 smaller than alpha $(\alpha=0.05)$ indicates that CAR has a significant effect on the amount of National Social Security on Employment (BPJS Ketenagakerjaan) deposit portfolio. Therefore, $\mathrm{Ha} 2$ which states that CAR has a significant positive influence on deposit portfolio of National Social Security on Employment (BPJS Ketenagakerjaan) is accepted.

The result of hypothesis testing for variable Loan to Deposit Ratio (LDR) has coefficient of 5,771721 which shows the positive direction of LDR variable to deposit portfolio of National Social Security on Employment (BPJS Ketenagakerjaan). Sig 0,0032 value smaller than alpha $(\alpha=0.05)$ indicates that LDR has a significant impact on the amount of deposit portfolio of National Social Security on Employment (BPJS Ketenagakerjaan). Thus, Ha3 which states that there is a significant impact between Loan to Deposit Ratio (LDR) to National Social Security on Employment (BPJS Ketenagakerjaan) Deposit Portfolio at bank that cooperates with National Social Security on Employment (BPJS Ketenagakerjaan) is accepted, $\mathrm{HO3}$ is rejected reveals that there is no significant influence between Loan to Deposit Ratio (LDR) Portfolio Deposit of National Social Security on Employment (BPJS Ketenagakerjaan) at the banks which are in cooperation with National Social Security on Employment (BPJS Ketenagakerjaan).

The result of hypothesis testing for Operational Expenses to Operating Income variable has a coefficient of $-28,25583$ indicating the negative direction of Operational Expenses to Operating Expenses variable to deposit portfolio of National Social Security on Employment (BPJS Ketenagakerjaan). A sig 0.0324 sig value smaller than alpha $(\alpha=0.05)$ indicates that Operational Expenses to Operating Income has a negative significant effect on the amount of National Social Security on Employment (BPJS Ketenagakerjaan) deposit portfolio. Therefore, Ha4 which states there is a significant influence between Operational Expenses to Operating Income on the Deposit Portfolio of National Social Security on Employment (BPJS Ketenagakerjaan) at the banks which are in cooperation with National Social Security on Employment (BPJS Ketenagakerjaan) is accepted, $\mathrm{H} 04$ rejected that there is no significant impact between Operational Expenses to Operating Income to the Deposit Portfolio of National Social Security on Employment (BPJS Ketenagakerjaan) at the banks which are in cooperation with National Social Security on Employment (BPJS Ketenagakerjaan).

\section{DISCUSSION OF RESULTS}

The Impact of Non Performing Loan (NPL) on Deposit Portfolio of National Social Security on Employment (BPJS Ketenagakerjaan). Based on the research that has been 
described above, NPL to deposit portfolio of National Social Security on Employment (BPJS Ketenagakerjaan) does not significantly affect the deposit portfolio of National Social Security on Employment (BPJS Ketenagakerjaan). It may be due to interest offered by banks in cooperation with National Social Security on Employment (BPJS Ketenagakerjaan) is not too concerned. NPLs are the most important interest offered by the bank concerned. This research is proven by the results of t test of 0.5097 greater than alpha $(\alpha=0.05)$. It is supported by Kamau and Njeru's (2015) research which states taht NPL does not have effect on customer placements in banks and Bayyoud and Sayyad's (2015) study which states that credit risk does not have significant effect on investment in banks.

The Impact of Capital Adequacy Ratio (CAR) on Deposit Portfolio of National Social Security on Employment (BPJS Ketenagakerjaan). Based on the research described above, CAR on the deposit portfolio of National Social Security on Employment (BPJS Ketenagakerjaan). From the research, it is found that CAR has a significant positive effect on National Social Security on Employment (BPJS Ketenagakerjaan) deposit portfolio shown by $t$ test result of 0.0002 which is smaller than alpha $(\alpha=0.05)$. It is supported by research by Paul R Masson, Tammim Bayoumi dan Hossein Sammiei (2014) the result CAR have a positive significant to saving money in the bank and Abu Hanif Md. Noman, Sajeda Pervin, Mustafa Manir Chowdhury\& Hasanul Banna (2015) the result that have significant between CAR on performance bank and decicion to saving money in the bank.

The Impact of Loan to Deposit Ratio (LDR) on Portfolio Deposit of National Social Security on Employment (BPJS Ketenagakerjaan). Based on the research described above, LDR to deposit portfolio of National Social Security on Employment (BPJS Ketenagakerjaan) has a significant positive effect on deposit portfolio of National Social Security on Employment (BPJS Ketenagakerjaan). The sig value shown by the t test of LDR is 0.0032 which is smaller than the alpha $(\alpha=0.05)$. It means that the higher the LDR of the bank, the more likely deposit portfolio of National Social Security on Employment (BPJS Ketenagakerjaan) in a bank in a particular bank will remain high, but it still considers the limits issued by Bank of Indonesia. The results of this study are supported by the research of Almekhlafi, Almekhlafi, Kargbo \& Hu (2016), Saaddaoui and Boujelbene (2015) and Mutava and Ali (2016) stating that liquidity risk positively affects bank performance.

The Impact of Operational Expenses to Operating Income on Deposit Portfolio of National Social Security on Employment (BPJS Ketenagakerjaan). Based on the research described above, the Operational Expenses to Operating Income on deposit portfolio of National Social Security on Employment (BPJS Ketenagakerjaan) has a significant negative effect on the deposit portfolio of National Social Security on Employment (BPJS Ketenagakerjaan). The sig value shown by the test is 0.032 smaller than the alpha $(\alpha=$ 0.05). It means that the higher the Operational Expenses to Operating Income of the bank, the possibility of the deposit portfolio of National Social Security on Employment (BPJS Ketenagakerjaan) in a bank is lowered, due to a large burden by the bank that could adversely affect earnings deposit of National Social Security on Employment (BPJS Ketenagakerjaan) or it will affect the interest rate reducer provided by the bank. It is supported by Muhammad Fahrul Rozi Syafi'i dan Ellen Rusliati (2016), Maytham Huseen Saeed (2014) and Yara Nurintan (2016) that the result have the negative impact to decicion saving money in the bank.

The Effect of Non Performing Laon, Capital Adequacy Ratio, Loan to Deposit Ratio and Operational Expenses to Operating Income on Deposit Portfolio of National Social Security on Employment (BPJS Ketenagakerjaan). Based on the results of the research described above, NPL, CAR, LDR and Operational Expenses to Operating Income simultaneously affect the deposit portfolio of National Social Security on Employment (BPJS Ketenagakerjaan). It is indicated by the result of $\mathrm{f}$-test for prob F-statistic $<\alpha(\alpha=5 \% 7)$ that is equal to 0,0000 . Therefore, $\mathrm{H} 0$ is rejected and $\mathrm{H} 1$ is accepted because the F-statistic prob is 0.0000 . 


\section{CONCLUSION}

Based on data analysis and hypothesis testing that has been done, then conclusion can be drawn as follows:

NPL, CAR, LDR and Operational Expenses to Operating Income variables have a significant effect on deposit portfolio of National Social Security on Employment (BPJS Ketenagakerjaan) period of testing period is 2015 until 2017. It can be concluded that NPL, CAR, LDR and Operational Expenses to Operating Income have a significant effect on deposit portfolio of National Social Security on Employment (BPJS Ketenagakerjaan). The amount of contribution of the influence of independent variables on deposit portfolio of National Social Security on Employment (BPJS Ketenagakerjaan) of $83.57 \%$ while the rest of $16.43 \%$ influenced by other variables outside the research variables. Therefore, the first research hypothesis that NPL, CAR, LDR and Operational Expenses to Operating Income simultaneously have a significant effect on the deposit portfolio of National Social Security on Employment (BPJS Ketenagakerjaan) is acceptable.

NPL variable partially has an insignificant positive effect on deposit portfolio of National Social Security on Employment (BPJS Ketenagakerjaan) period 2015 to 2017. It can be concluded that NPL partially does not have a significant influence on the deposit portfolio of National Social Security on Employment (BPJS Ketenagakerjaan) period 2015 until 2017. The amount of contribution of NPL influence on deposit portfolio of National Social Security on Employment (BPJS Ketenagakerjaan) of 0.5097\%; thus, the research hypothesis that NPL negatively affecting deposit portfolio of National Social Security on Employment (BPJS Ketenagakerjaan) is rejected.

CAR variable partially has a positive effect on deposit portfolio of National Social Security on Employment (BPJS Ketenagakerjaan) period 2015 to 2017. It can be concluded that CAR partially has a significant positive effect on deposit portfolio of National Social Security on Employment (BPJS Ketenagakerjaan) period 2015 until 2017. The amount of contribution of the effect of the CAR on the deposit portfolio of National Social Security on Employment (BPJS Ketenagakerjaan) of 0.0002; therefore, the hypothesis stating that market risk does not affect the deposit portfolio of National Social Security on Employment (BPJS Ketenagakerjaan) is rejected for CAR variable.

LDR variable partially has a positive effect on deposit portfolio of National Social Security on Employment (BPJS Ketenagakerjaan) period 2015 to 2017. It can be concluded that Loan to Deposit Ratio partially has a significant positive effect on deposit portfolio of National Social Security on Employment (BPJS Ketenagakerjaan) period 2015 until 2017. The amount of contribution of effect of LDR on deposit portfolio of National Social Security on Employment (BPJS Ketenagakerjaan equal to 0,0032 so that hypothesis which states that LDR have positive effect on deposit portfolio of National Social Security on Employment (BPJS Ketenagakerjaan) is accepted.

Operational Expenses to Operating Income partially have a negative effect on deposit portfolio of National Social Security on Employment (BPJS Ketenagakerjaan) period 2015 until 2017. It can be concluded that Operational Expenses to Operating Income partially has a significant negative effect on the deposit portfolio of National Social Security on Employment (BPJS Ketenagakerjaan) period 2015 until 2017. The amount of contribution of effect of BOPO to deposit portfolio of National Social Security on Employment (BPJS Ketenagakerjaan) equal to 0,032 so that hypothesis which states that Operational Expenses to Operating Income has negative effect to deposit portfolio of National Social Security on Employment (BPJS Ketenagakerjaan) is accepted.

Therefore, the BI Rate, SB SUN, LDR and BOPO can be used as an alternative to analyze the total placement of deposits in investing, but the NPL cannot be used as an alternative in analyzing the shares to decide the placement of deposits in investing because it is still unexplained in National Social Security on Employment (BPJS Ketenagakerjaan). 


\section{REFERENCES}

1. Abdellahi, S. A., Hussein, S. \& Mashkani, A. J. (2017). The effect of credit risk, market risk, and liquidity risk on financial performance indicators of the listed banks on Tehran Stock Exchange. American Journal of Finance and Accounting, Vol. 5, No. 1, 2017.

2. Almekhlafi, E., Almekhlafi, K., Kargbo, M., \& Hu, X. (2016). Study of Credit Risk and Commercial Banks' Performance in Yemen: Panel Evidence. Journal of Management Policies and Practices. June 2016, Vol. 4, No. 1, pp. 57-69. ISSN: 2333-6048)

3. Arwidanta, K. T. (2016). Pengaruh risiko kredit dan Suku Bunga Surat Utang Negara terhadap profitabilitas dengan kecukupan modal sebagai variabel mediasi. E-Jurnal Manajemen Unud, Vol. 5, No. 4, 2016: 2311-2340 ISSN : 2302-8912

4. Baltagi, B. H. (2005). Econometrics Analysis of Panel Data. Third edition. John Wiley \& Sons Ltd. Chinester.

5. Baltagi, B. H. (2008). Econometrics. Fourth edition. Springer Verlag. Berlin Heidelberg

6. Bayyoud, M., \& Sayyad, N. (2015). The Relationship between Credit Risk Management and Profitability between Investment and Commercial Banks in Palestine. International Journal of Economics and Finance, Vol. 7, No. 11; 2015 ISSN 1916-971X E-ISSN 19169728

7. Chatarine, A., Wiagustini, L. P., \& Sriartini, L. G. (2016). Pengaruh Risiko Kredit dan Risiko Nilai Tukar terhadap Profitabilitas dan Return Saham Perbankan di BEI. E-Jurnal Ekonomi dan Bisnis Universitas Udayana, Vol. 5, No. 11 (2016): 3683-3712 3683. ISSN : 2337-3067

8. Kamau, F. \& Njeru, A. (2015). Effect of Liquidity Risk on FinancialPerformance of Insurance Companies Listed at the Nairobi Securities Exchange. International Journal of Science and Research (IJSR) ISSN (Online): 2319-7064.

9. Levine, R. (1997). Financial Development and Economic Growth: Views and Agenda.

10. Mutava, P. M. dan Ali, A. I. (2016). Effects of Credit Risk Management on Financial performance of Commercial Banks in Mombasa County. Research Journal of Finance and Accounting ISSN 2222-1697 (Paper) ISSN 2222-2847 (Online) Vol.7, No.17, 2016.

11. Nurintan, Y. (2016). Pengaruh Penerapan Manajemen Risiko Kredit, Risiko Pasar, Risiko Likuiditas dan Risiko Operasional Terhadap Kinerja Keuangan Perbankan. E-Jurnal Ekonomi dan Bisnis Universitas Udayana, Vol. 5, No. 11, (2016): 3791-3892 3791. ISSN : 3327-3393.

12. Rosadi, D. (2011). Ekonometrika \& Analisis Runtun Waktu Terapan.

13. Saaddaoui, A. \& Boujelbene, Y. (2015). Liquidity and Credit Risk in the Emerging Financial Markets. International Journal of Economics and Financial Issues. ISSN: 25465264

14. Saeed, M. H. (2014). Examining the Relationship between Operational Risk, Credit Risk and Liquidity Risk with Performance of Malaysia. International Journal of Science and Research (IJSR) ISSN (Online): 2119-8354

15. Sekaran, U. \& Roger, B. (2013). Research Methods for Business. United Kingdom.

16. Sembodo, H. (2013). Pemodelan Regresi Panel pada Pendapatan Asli Daerah (PAD) dan Dana Alokasi Umum (DAU) Terhadap Belanja Daerah. Jurnal Mahasiswa Statistik, Vol. 1, No. 4, pp. 297-300.

17. Syafi'l, M. F. R. \& Rusliati, E. (2016). Credit Risk, Market Risk, Operational Risk and Liquidity Risk on Profitability of Banks in Indonesia. Trikonomika, Vol. 15, No. 2, December 2016, Page. 78-88. ISSN 1411-514X (print) / ISSN 2355-7737.

18. Wibisono, D. (2005). Metode Penelitian \& Analisis Data. Salemba Medika. Yogyakarta: C. V. Andi Offset. 